\section{On the margins of Europe}

SIR-Your leading article (Nature 348, $375 ; 1990)$ catalogues the decline in the fortunes of British research and higher education but does not address the fundamental issue of whether the Britain of the 1990 s will get value for money from its expenditure on these activities.

There are two justifications for research funding: (1) investment leading directly to innovations of commercial value; (2) training individuals who will do innovative research in industry. Both justifications assume that Britain contains numerous technology-based companies capable of benefiting from this investment. We have only to look around us to see that this is untrue. Britain acts as an offshore manufacturing base for companies that carry out their research and development elsewhere, while independent British manufacturers service these companies with low-technology products that are cheaper to manufacture here than overseas. Economic growth in the past decade has been concentrated in the service sector, which is not renowned for its interest in leadingedge technology. People are making excellent livings from these activities and they are entitled to ask why they should spend their money on research that does not enhance their prosperity.

This argument extends to the whole of higher education. The shift to entrepreneurial values means that the skills engendered by the higher education system are not high on the agenda of employers, who recruit graduates because the intellectually ablest school-leavers insist on entering higher education, but who both despise the values embodied in higher education and bitterly resent the costs to them through taxation.

Our neighbours recognize that prosperity comes through advanced, highvalue-added products that can be manufactured only in countries with the necessary intellectual infrastructure. Previous British administrations have recognized this but not the importance of encouraging commercial initiative. The present administration has supported individual enterprise but has undermined the infrastructure while still spending heavily on it. Present patterns of employment, as encouraged by the government, do not require either state-funded research or a massive higher education system, so the government should have the courage of its convictions and eliminate, once and for all, the enormous tax burden they entail and divert the money back to employers for training. The urgent question is whether current levels of prosperity can be sustained on this basis given that the bubble of the service sector has already burst, with disastrous consequences, and our attractiveness as an offshore manufac- turing base is threatened by competition from our European neighbours. If it genuinely wants Britain to remain prosperous into the next century, the government might consider putting enough money into research and higher education to prevent their physical disintegration and the total demoralization of their staff. Failure to do so will marginalize Britain in Europe more surely than the histrionics of any single member of the cabinet.

$$
\text { C. R. LEGG }
$$

Department of Social Sciences,

City University,

Northampton Square,

London EC1V OHB, UK

\section{Who speaks for science?}

SIR - There has been extensive reporting in your columns in recent years about the declining plight of British science and the declining morale of British scientists, and the most active body publicly lobbying support for the British scientific base seems to be Save British Science. It must surely be asked what is the position of Royal Society? This is the traditional body of eminent scientists who could speak with real authority on the causes, consequences and solutions to the current situation. The Royal Society should be the voice to which British scientists, both at home and abroad, would turn for leadership; unfortunately, the voice seems mute.

Department of Immunology,

Peter M. JOHnson

University of Liverpool,

PO Box 147 ,

Liverpool L69 3BX, UK

- See News, page 183.

\section{Soul not for sale}

SIR - In response to Philip Siekevitz's letter "Science sells its soul" (Nature 347, $509 ; 1990)$, as a young researcher I disagree with his assertion that commercialization of research by university departments is an abhorrent corruption of their founding philosophy. UK science biomedical in particular - is in a cash crisis. The ultrapurist allure of science he describes belongs to an almost utopian era when sufficient funds existed for science projects to be pursued irrespective of cost. This is a mythical assumption based largely on a British imperial legacy of "gentleman scientists"

Entry into science was and still is based on this popular press image. My soul and motivation are still driven by the allure of which he speaks. For example, I have for three years been a weekend shopworker at Marks \& Spencers - as well as a weekday research fellow. However, I now embrace links with money-making biotechnology companies with open arms. This may seem to him to be selling my soul but I believe it is a realization of the current facts of life (if not science).

Nature has frequently reported the shortage of government cash coming from the Medical Research Council. This is further reflected in a reduction of grants from the cancer charities. It is becoming increasingly difficult, if not impossible, for newcomers to gain grants in competition with established large research groups, especially now that even these are being cut (Nature 347, 324; 1990).

Courting biotechnology companies is the only alternative. It provides, for me at least, a possible source of cash for a newcomer. It helps to fund and expand the research to which the allure of science has made me an addict. Making discoveries, pursuing chance observations to their conclusion, and, of course, being recognized for the scientific endeavour, is still my prime motivation. However, I will advise, produce methodologies, contract for research, evaluate products and sell purified proteins willingly to any biotechnology company.

Sir, I have not sold my soul, but I will prostitute my principles to keep my soul alive.

RAY ILES

Joint Academic Unit of Obstetrics Gynaecology and Reproductive

Physiology,

St Bartholomew's Hospital Medical

College and the London Hospital

Medical College,

West Smithfield, London EC1A 7BE, UK

\section{Did anyone know Frederick Soddy?}

SIR-I am writing a biography of Frederick Soddy, 1877-1956. He collaborated with Rutherford on the very early radioactive research at $\mathrm{McGill}$ in Montreal in 1903-04 and was awarded the Nobel Prize for his work on isotopes. $\mathrm{He}$ was at the Universities of Glasgow, Aberdeen and finally Oxford until his early retirement. During the latter period he had the reputation of being something of a crank because of his interest in monetary reform.

I would be very interested to hear from anyone who knew him or knew of him or can offer any suggestions for sources of information about him.

LINDA MERRICKS

School of Cultural

and Community Studies,

University of Sussex,

Arts Building, Falmer,

Brighton, Sussex BN1 9QN, UK 